\title{
THE STRUCTURE OF THE MAMMILLARY LAYER OF THE DOMESTIC HEN'S EGG-SHELL
}

\author{
D.-S. ROBINSON \\ Agricultural Research Council, Food Research Institute, \\ Colney Lane, Norwich Nor 70 F (Great-Britain)
}

Materials and methods used in the studies presented in this review have been described elsewhere (RobInson and KING, I968 $a, b$ ). Histochemical tests used included the following.

\section{Method}

Alcian Blue 8GX at $\mathrm{pH} 2.5$

Alcian Blue $8 \mathrm{GX}$ at $\mathrm{pH}$ r.o

Periodic acid-Schiff reagents

Aldehyde-fuchsin reagent

Alcian Blue-Magnesium chloride reagents

$2,2^{1}$-dihydroxy-6,6-1 dinaphthyldisulphide (DDD)
Reactive groups

sialo- and sulphate

sulphate groups

glycol groups

sulphate groups

acidic groups

sulphydryl groups

The specificity of these methods for egg shell membranes and reproductive tract mucins was verified by studying the effects of methylation, saponification, acetylation and deacetylation on the staining properties of the tissues. To prove that only glycol groups were reacting with the periodate-Schiff reagents it was necessary to study also the effects of 2,4,-dinitrophenylhydrazine and dimedone on the Schiff stain applied to previously oxidized samples. To establish that the DDD reagent was reacting specifically with sulphydryl groups, alkylation with either o.r M iodoacetic acid titrated to $\mathrm{pH} 8.0$ with o.IN sodium hydroxide for $20 \mathrm{~h}$ at $37^{\circ} \mathrm{C}$, or with o.IM N-ethylmaloimide in o.IM phosphate buffer at pH 7.4 for $4 \mathrm{~h}$ at $37^{\circ} \mathrm{C}$, was introduced before reaction with DDD reagent. Disulphide groups were detected as sulphydryl groups after reduction with either sodium sulphite ( $\mathrm{p}$. IoO w/v) at $\mathrm{pH}$ 8.0 or $0.5 \mathrm{M}$ thioglycollic acid titrated to $\mathrm{pH} 8.0$ with IN soditum hydroxide. 


\section{Histochemical detection of carbonic anhydrase}

Thin mammillary membranes (I $7 \mu$ ) were placed on the surface of a solution containing cobalt sulphate $(0.0 \mathrm{I} 8 \mathrm{M})$ and sodium bicarbonate $(0.2 \mathrm{IM})$ at $\mathrm{pH} 7.5$ (PEARSE I960) and incubated at $32^{\circ} \mathrm{C}$ for one hour. The membranes were then washed thoroughly in distilled water and placed in a solution of ammonium sulphide $(5 \mathrm{p}$. Ioo $\mathrm{v} / \mathrm{v}$ ) for I mn. Control experiments to test for unspecific adsorption of cobalt ions were carried out in the cobalt solutions without sodium bicarbonate. The $\mathrm{pH}$ value of these solutions was adjusted to 7.5 with o.IM sodium hydroxide. Tests were also carried in the cobalt bicarbonate solutions containing $4 \times \mathrm{IO}^{-1}$ to $4 \times \mathrm{IO}^{-2} \mathrm{M}$. Diamox (2-acetylamine-I,3,4-thiadiazole-5-st1phonamide sodium). Membranes which had been heated in boiling distilled water for $15 \mathrm{mn}$. were also examined.

The mammillary layer of the domestic hen's egg shell is embedded partly in the outer shell membrane and is responsible for the attachment of the major part of the shell to the keratin-like shell membranes which enclose the albumen. Our earlier finding (RoBINson and KING, I963) which showed that a thin layer (I7 $\mu$ ) of the outer shell membrane with attached organic mammillary cores can be obtained by simple manipulation and little decalcification has provided a rapid method for preparing the mammillary region of the shell, free of the other layers of shell membrane and of other shell matrix substances. This rigid layer of membrane is acceptable for histochemical studies without prior fixation or treatment with strong alkali.

The membrane consists of a network of fibres which penetrate the organic parts of the mammillary cores. The staining by the Schiff reagent of the periodate-oxidized organic mammillary cores, and the observations which show that this reaction is blocked by either phenylhydrazine and dimedone reagents or prior acetylation of the membranes, establishes that the cores contain substances with glycol groups. The failure of the membrane and the organic mammillary cores to stain with Alcian Blue at $\mathrm{pH} 2.6$ has indicated the absence of acidic groups. However, alcianophilic substances which surround the cores have been observed in cross-sections of formalin-fixed whole shell membranes obtained from pieces of decalcified shell. The substances were stained by Alcian Blue at $\mathrm{pH}$ 2.6, but not at $\mathrm{pH}$ I.o, were easily washed from the core surfaces, and are believed to contain sialomucins. It is thought that the presence of these loosely bound alcianophilic substances on membranes obtained from formalin-fixed shells may be due to high concentrations of shell matrix at the tips of the cores, as described by TEREPKA (I963), because the histochemical tests with the specific DDD reagent have shown that the true cores which contain the neutral mucins are bound to the membrane fibres by disulphide bonds.

The occurrence in actively secreting isthmus tissues of only neutral mucins together with the observation that eggs isolated from the isthmus contained crystalline mammillary cores shows that the mammillary cores are formed in the isthmus and also that shell formation is nucleated in the isthmus. However, the chemistry of the processes which result in deposition of the cores and nucleation of crystal formation is not known, although histochemical tests have indicated that a carbonic anhydrase enzyme is localized at the mammillary cores (RoBINson and KING, I963). 
The histochemical test for carbonic anhydrase which results in localized precipitation of cobalt sulphide at the cores, is easily observed only with the specially prepared thin mammillary membranes. The use of pieces of whole decalcified shell for this histochemical test (DiAmantstein, BRONSCH and SchlüNS, I964) is unsatisfactory, as the cobalt ions present in the reaction mixture are either unspecifically absorbed or included in the thicker shell and membrane structures and this accounts for the failure of these workers to detect carbonic anhydrase histochemically. Nevertheless, until a carbonic anhydrase enzyme can be demonstrated by other tests on the prepared mammillary membranes its presence cannot be established, even though the observed bicarbonate-dependent retention of cobalt is prevented by either a specific carbonic anhydrase inhibitor or by heat denaturation of samples of the mammillary membrane. However, if a carbonic anhydrase enzyme is present in the mammillary core, it seems likely that its presence might have aided calcification either prior to or after the formation of the organic core by localizing a high concentration of carbonate anion derived from either bicarbonate anions or metabolically produced carbon dioxide. Furthermore, the presence of such an enzyme at the mammillary cores may aid resorption of inorganic carbonates by a developing embryo and therefore would also offer an explanation for the observed localized dissolution of shell at the sites of the mammillary cores in hatched egg shells (TYLER and SIMKISS, I959; SCHMIDT, I965; TEREPKA, I963).

Very recent studies (RoBINSON and KING, I969) have shown that the structure of the mammillary layer of the shell may also be important from another point of view, in that the distribution, microscopical structure and staining property of the organic mammillary cores present in weak thin shells has been found to be abnormal.

\section{SUMMARY}

The microscopic structure, the histochemical properties and a proposed function of the mammillary layer of the domestic hen's egg shell is described. It is concluded that the organic parts of the mammillary cores which are secreted in the isthmus contain mainly neutral mucopolysaccharides and that the integrity of the cores is maintained by disulphide bonds. The histochemical evidence for the presence of carbonic anhydrase is represented. A relationship between the strength of some egg shells and the microscopic structure of the mammillary part of the outer shell membrane is illustrated.

\section{RÉSUMÉ}

STRUCTURE DE IA COUCHE MAMILIAIRE DE LA COQUILLE D'CEUF DE POULE

Nous décrivons la structure microscopique, les propriétés histochimiques ainsi qu'une fonction supposée de la couche mamillaire de la coquille d'ouf de poule domestique. Nous en concluons que la partie organique des noyaux mamillaires, qui est sécrétée dans l'isthme, contient principalement des mucopolysaccharides neutres et que l'intégrité de ces noyaux est maintenue par des liens disulfures. Nous donnons une nouvelle preuve histochimique de la présence d'anhydrase carbonique et illustrons une relation entre la solidité de certaines coquilles d'œuf et la structure microscopique de la partie mamillaire de la membrane coquillière externe. 


\section{REFERENCES}

Diamantstein T., Bronsch K., Schluns F., I964. Carbonic anhydrase in the mammillae of the heli's egg shell. Nature, 203, 88-89.

Pearse A. G. E., I960. Histochemistry, Theoretical and Applied. J. and A. Churchill, London.

Robinson D. S., KING N. R., I963. Carbonic anhydrase and formation of the hen's egg shell. Nature, 199, $497-498$.

Robinson D. S., King N. R., Ig68 a. Mucopolysaccharides of an avian egg shell membrane. J. roy. micr. Soc., 88, I3-22.

Robinson D. S., KIng N. R., I 968 . The occurrence of neutral and acidic mucins in the reproductive tract of the laying hen. Histochemie, 13, 97-I04.

Robinson D. S., King N. R., I97o. The distribution of organic mammillary core substances in weak egg shells. Brit. Poultry Sci., 11, 39-44.

Schmid T. J., I965. Morphologie der kalkresorption an der ausgebrüteten vogel eischale. Z. zellforsch., 68, $874-892$.

Terepka A. R., r963. Organic-inorganic interrelationships in avian egg shell. Explt. cell Res., 30, I83I92.

lyler C., Simkiss K., I959. Studies on egg shells XII. Some changes in the shell during incubation. J. Sci. Food Agric, 10, 6rI. 